\title{
The hepatoprotective effects of Pyrus biossieriana buhse leaf extract on tert-butyl hydroperoxide toxicity in HepG2 cell line
}

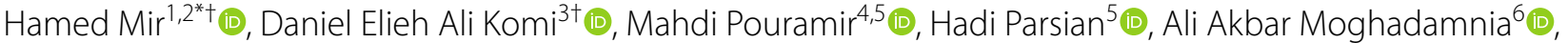 \\ Nayer Seyfizadeh ${ }^{7}$ and Mostafa Lakzaei ${ }^{4}$ (D)
}

\begin{abstract}
Objective: In present study, the effects of the leaf extract of Pyrus biossieriana Buhse on tert-Butyl hydroperoxide (t-BHP) induced toxicity in the HepG2 cell line were investigated.

Results: HepG2 cells were exposed to different concentrations of both extract $(1.5,2.0$, and $2.5 \mathrm{mg} / \mathrm{mL})$ and t-BHP $(100,150$, and $200 \mu \mathrm{M})$. The total flavonoid and phenolic contents, the cell viability, lipid peroxidation, NO generation, and the total antioxidant capacity in cell media were assessed. The amount of arbutin was estimated $12.6 \%$ of the dry weight of leaves (equivalent to $126 \mathrm{mg} / \mathrm{g}$ ). Additionally, the amounts of flavonoids and phenols in extract were estimated $119 \mathrm{mg} / \mathrm{g}$ and $418 \mathrm{mg} / \mathrm{g}$, respectively. The cells incubated with t-BHP showed a significant decrease in survival ( $p<0.001)$. Preincubation with extract $(1.5 \mathrm{mg} / \mathrm{mL}$ and $2.0 \mathrm{mg} / \mathrm{mL})$ attenuated the t-BHP toxicity and increased the cell viability in cells exposed even to the highest concentration of t-BHP $(200 \mu M)(p$ value $<0.001$, and $p$ value $=0.035$ ) respectively. Additionally, treatment with extract reduced the cell growth suppression caused by $\mathrm{t}$-BHP. The P. biossieriana Buhse leaf extract at concentrations of 1.5 and $2.0 \mathrm{mg} / \mathrm{mL}$ is capable of attenuating t-BHP-induced cytotoxicity in HepG2 cells.
\end{abstract}

Keywords: Antioxidant, Cytotoxicity, HepG2 cell line, Pyrus biossieriana Buhse, tert-Butyl hydroperoxide

\section{Introduction}

The leaf extract of Pyrus biossieriana Buhse (a native tree that grows in the north of Iran) has been previously reported to possess anti-hyperglycemic, anti-hyperlipidemic, and antioxidant properties [1]. These leaves contain arbutin which is a glucoside of hydroquinone $[2,3]$. Arbutin attenuates oxidative stress and cognitive impairment [4]. In hepatocytes, tert-Butyl hydroperoxide (t-BHP) is metabolized by cytochrome P-450 [5-7] and the produced free radical intermediates contribute

\footnotetext{
*Correspondence: hmdmir3@gmail.com

${ }^{\dagger}$ Hamed Mir and Daniel Elieh Ali Komi contributed equally to this work

${ }^{1}$ Department of Nutrition, School of Allied Medical Sciences, Ahvaz

Jundishapur University of Medical Sciences, Ahvaz, Iran

Full list of author information is available at the end of the article
}

to oxidative stress [2]. t-BHP initiates the cell death and induces mitochondrial dysfunction [8]. t-BHP mediated oxidative stress may result in DNA damage in cells through the formation of hydroxyl radicals $[9,10]$. HepG2 cell line is a human hepatocellular carcinoma and nontumorigenic cell line widely used as an in vitro alternative to primary human hepatocytes in metabolism and hepatotoxicity investigations [11].

\section{Main text}

\section{Materials and methods}

Materials

HepG2 cell line was purchased from Pasteur instituteIran. RPMI 1640, Fetal Bovine Serum (FBS), Penicillin-Streptomycin (Pen-Strep $\left.{ }^{\circledR}\right)$, MTT solution, trichloroacetic acid (TCA), Arbutin (HPLC grade), and 
trypan blue were purchased from Sigma-Aldrich Chemical Co, UK. t-BHP was purchased from Merck Co, Germany.

\section{Preparing Pyrus biossieriana Buhse leaf extract}

The fresh leaves of $P$. biossieriana Buhse were collected from Babol city-Iran, washed, dried for 6 days, and then chopped. $400 \mathrm{~g}$ of powder was extracted with $2000 \mathrm{~mL}$ methanol (63\%). The methanol portion was evaporated using a rotary evaporator. The extract was stored at $-70{ }^{\circ} \mathrm{C}[1,12]$.

\section{Determining the arbutin and flavonoid content of the extract} The arbutin content of the extract was measured by HPLC. The calibration curve for arbutin over the known concentration range was linear $(r=0.99)$ (Fig. 1a) We performed HPLC using a Knauer Smartline Liquid Chromatography System (Knauer, Germany). Similar to our previous investigation [1], we used a Prontosil \#60-5, C18 $\mathrm{H}$ column that was $4.6 \mathrm{~mm}$ in diameter and $250 \mathrm{~mm}$ in length. The mobile phase consisted of a 50:50 mixture of methanol and water containing $1 \%$ acetonitrile. We set the flow rate at $0.7 \mathrm{~mL} / \mathrm{min}$ [1]. The percentage of arbutin recovered was determined by spiking a sample containing $7573 \mathrm{mg} / \mathrm{L}$ arbutin with an arbutin standard solution $(2500 \mathrm{mg} / \mathrm{L})$ to yield solutions with final concentrations of 7065, 6304, and $5036 \mathrm{mg} / \mathrm{L}$. HPLC for standard arbutin $(2500 \mathrm{mg} / \mathrm{L})$ was performed using a Eurospher C-18 column $(4.6 \times 250 \mathrm{~mm})$, mobile phase (methanol/water 50/50; flow rate: $0.7 \mathrm{~mL} / \mathrm{min}$ ) and was detected in $286 \mathrm{~nm}$ wavelength $[1,12,13]$ (Fig. 1b) We then run an HPLC to detect arbutin in the extract and another HPLC for arbutin in extract and hydroquinone (as internal standard), in the same condition (Fig. 1c, d).

\section{Determination of the total phenolic content}

The total amount of phenolic compounds was determined by Folin-Ciocalteu reagent using the method described by Singleton and Rossi with some modifications [14]. In brief, $1 \mathrm{~mL}$ of extract (diluted tenfold), was mixed with $5 \mathrm{~mL}$ Folin-Ciocalteu reagent (diluted 1:10 with ultrapure water). After $2 \mathrm{~min}, 4 \mathrm{~mL}$ of sodium carbonate solution $(75 \mathrm{~g} / \mathrm{L})$ was added and kept at room temperature for $2 \mathrm{~h}$. The absorbance was measured at
$765 \mathrm{~nm}$. Total phenolic content was expressed as gallic acid equivalent (GAE) in milligrams per gram [15] (Fig. 1e).

\section{Determination of the total flavonoids content}

The total amount of flavonoids was determined using aluminum chloride (quercetin was used as standard). Different concentrations of standards were prepared in $60 \%$ methanol. $1 \mathrm{~mL}$ sample/standard was incubated in the test tube, then $1 \mathrm{~mL}$ of $2 \%$ aluminum chloride was added to each tube. Finally, $6 \mathrm{ml}$ potassium acetate was added and OD was measured after $40 \mathrm{~min}$ at $415 \mathrm{~nm}$ [16].

\section{Cell culture}

HepG2 cells were plated in 24 multi-well flat-bottom culture plates, at $1.7 \times 10^{5}$ cells per well and incubated ( $37{ }^{\circ} \mathrm{C}$ with $5 \% \mathrm{CO}_{2}$ and $95 \%$ humidity) for $48 \mathrm{~h}$. HepG2 cells were then divided into 16 groups each including 5 wells. The wells were exposed to different concentrations of extract $(1.5 \mathrm{mg} / \mathrm{mL}, 2.0 \mathrm{mg} / \mathrm{mL}$, and $2.5 \mathrm{mg} / \mathrm{mL})$ prepared in complete media, and incubated for $24 \mathrm{~h}$. After $24 \mathrm{~h}$ the media were removed and wells were washed twice with sterile distilled water, then different concentrations of t-BHP $(0,100 \mu \mathrm{M}, 150 \mu \mathrm{M}, 200 \mu \mathrm{M})$, were dissolved in complete media and were added to all groups, except control and incubated for $24 \mathrm{~h} \mathrm{[2]}$.

\section{Cell viability assay (MTT assay)}

$200 \mu \mathrm{L}$ of MTT solution was added to each well and incubated at $37^{\circ} \mathrm{C}$ in dark place for $4 \mathrm{~h}$. Acid-isopropanol (as calibrator) ( $1 \mathrm{~mL}$ of $0.04 \mathrm{~N} \mathrm{HCl}$ in isopropanol) was added to all wells and mixed thoroughly to dissolve dark blue crystals [17]. Using a spectrophotometric method, all wells were read at $570 \mathrm{~nm}$ as test and $630 \mathrm{~nm}$ as reference wavelengths [18].

\section{Total antioxidant capacity (TAC)}

Using ferric-reducing antioxidant power (FRAP), the total antioxidant capacity (TAC) of samples was measured. [19]. $1.5 \mathrm{~mL}$ of FRAP reagent was added to test tubes, incubated at $37^{\circ} \mathrm{C}$ for $5 \mathrm{~min}$, then $50 \mu \mathrm{L}$ of HepG2 cells media (test solution) was added to tubes, mixed thoroughly, and incubated in $37^{\circ} \mathrm{C}$ for $15 \mathrm{~min}$. The absorbance was read at 593 [19].

(See figure on next page.)

Fig. 1 a Calibration curve for arbutin over the known concentration range $(r=0.99)$, b HPLC for standard arbutin (2500 mg/L) using a Eurospher C-18 column ( $4.6 \times 250 \mathrm{~mm}$ ), mobile phase (methanol/water 50/50; flow rate: $0.7 \mathrm{~mL} / \mathrm{min}$ ) detected in $286 \mathrm{~nm}$ wavelength, $\mathbf{c}$ HPLC to detect arbutin in extract, using the same kind of Eurospher column and detected it in $286 \mathrm{~nm}, \mathbf{d ~ H P L C}$ for arbutin in extract and hydroquinone (as internal standard), in similar mobile phase, flow rate, and detection wavelength, e standard cure for phenols was drown using gallic acid 

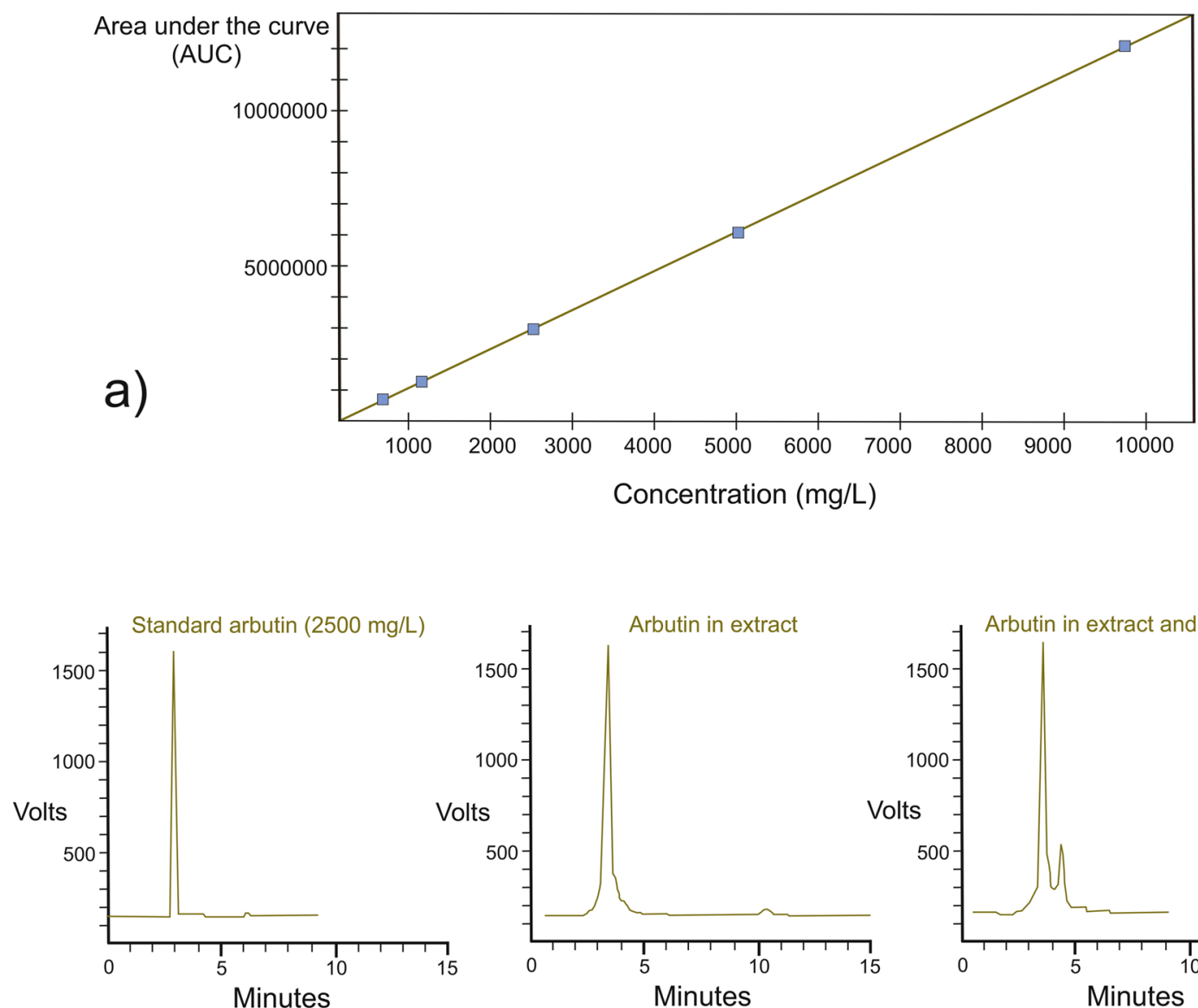

b)

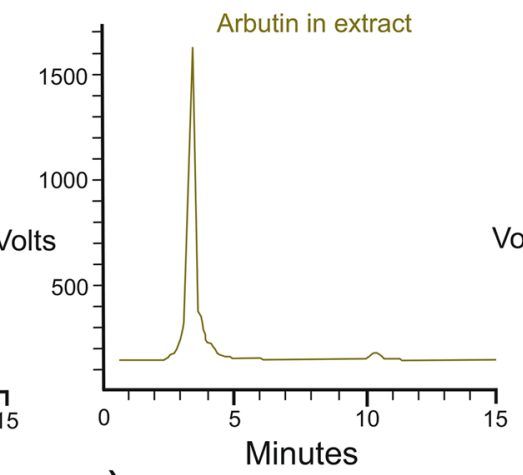

c)

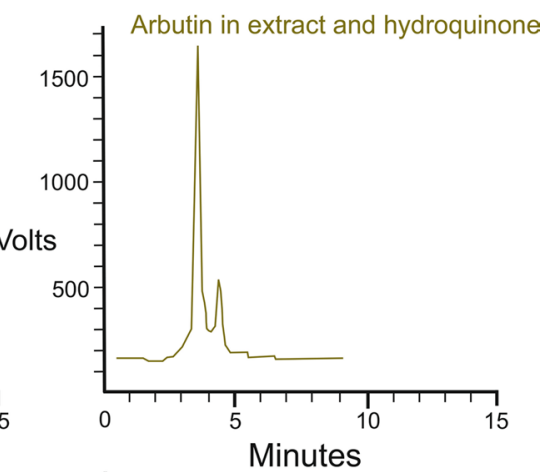

d)

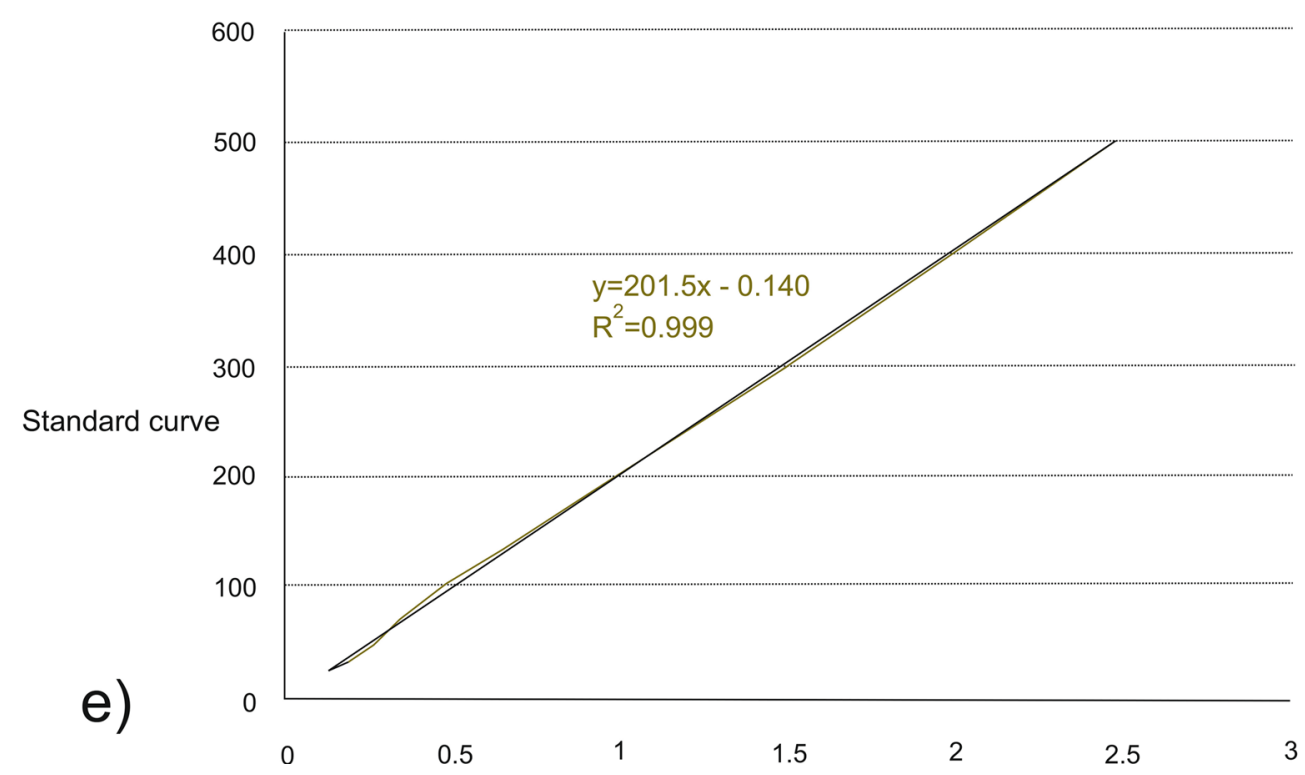

Fig. 1 (See legend on previous page.) 


\section{NO generation}

The Griess reagent system is based on the chemical reaction which uses sulfanilamide (SA) and N-1-naphthyl ethylenediamine dihydrochloride (NED) under acidic (phosphoric acid) conditions. This system detects $\mathrm{NO}_{2}$ in a variety of biological samples. $50 \mu \mathrm{L}$ of samples and 50 $\mu \mathrm{L}$ of sulfanilamide were mixed gently in a microtube and incubated in dark place for $5 \mathrm{~min} .50 \mu \mathrm{L}$ NED was also added to each microtube. Then $50 \mu \mathrm{L}$ Vanadium chloride (VCL3) was added to all samples, incubated at $37^{\circ} \mathrm{C}$ for 45- $60 \mathrm{~min}$ and the absorbance of each tube was read at $540 \mathrm{~nm}[20]$.

\section{Lipid peroxidation}

Lipid peroxidation was estimated by TBARS assay, a colorimetric test for determining lipid peroxidation, based on the reaction of 2-Thiobarbituric Acid (TBA) and MDA. $0.5 \mathrm{~mL}$ of cell media was added to the tube containing $2 \mathrm{~mL}$ of reagent, mixed thoroughly, and incubated in boiling water for $15 \mathrm{~min}$, allowed to reach room temperature, then centrifuged in 1500 RPM for $5 \mathrm{~min}$. The OD of samples were read at $593 \mathrm{~nm}$ [21].

\section{Statistics analysis}

All groups were containing 5 wells $(\mathrm{N}=5)$, except for MTT that was performed in triplicate $(\mathrm{N}=3)$ to check the reproducibility. Results are presented as the mean \pm standard deviation (SD). Statistical analysis was performed using one-way analysis of variance (ANOVA) with subsequent post hoc comparisons by LSD (SPSS, Ver 21.0, IBM-USA). The criterion for statistical significance is expressed as $\mathrm{p}<0.05$. The normality of data was checked using the Kolmogorov-Smirnov test.

\section{Results}

The arbutin content of the extract was measured by HPLC (12.6\% of the dry weight of the leaves). The total flavonoid and phenolic contents in the extract were $119 \pm 6.93 \mathrm{mg} / \mathrm{g}$ and $418 \pm 10.07 \mathrm{mg} / \mathrm{g}$ respectively. All groups that received $\mathrm{t}-\mathrm{BHP}$ and extract, showed significantly reduced cell viability when compared to the control group. Incubation of cells with the extract alone partially reduced their viability in a dose-dependent manner in which incubation of cells with the extract at different concentrations of $1.5,2.0$, and $2.5 \mathrm{mg} / \mathrm{mL}$ reduced the cell viability to $94.36 \pm 2.56 \%(\mathrm{p}<0.016)$, $81.99 \pm 2.07 \%(\mathrm{p}<0.001)$, and $73.25 \pm 1.81 \%(\mathrm{p}<0.001)$ respectively. In the group treated with the extract concentration of $1.5 \mathrm{mg} / \mathrm{mL}$ and $200 \mu \mathrm{M} \mathrm{t}-\mathrm{BHP}$, the cell viability decreased to $72.52 \pm 1.1 \%(\mathrm{p}<0.001)$. The minimum rate of cell viability was observed when t-BHP at the concentration of $200 \mu \mathrm{M}$ was added to cells pretreated with $2.5 \mathrm{mg} / \mathrm{mL}$ of extract. In this case, the cell viability dropped to $43.48 \pm 3.20 \%(\mathrm{p}<0.001)$. Indeed, preincubation of HepG2 cells with extract $(1.5 \mathrm{mg} /$ $\mathrm{mL}$ and $2.0 \mathrm{mg} / \mathrm{mL}$ ) attenuated $\mathrm{t}$-BHP toxicity when the groups exposed to all concentrations of $t-B H P(p$ values $<0.001$ ) (Table 1) Exposure to high levels of

Table 1 The effect of pyrus biossieriana buhse leaf extract and t-BHP treatment on the cell viability of HepG2 cell line

\begin{tabular}{|c|c|c|c|c|c|c|c|c|}
\hline $\begin{array}{l}\text { Control } \\
100.0 \pm 1.10\end{array}$ & & $p$ value & $\begin{array}{l}\mathrm{t} 100 \\
72.86 \pm 2.10\end{array}$ & & p value & $\begin{array}{l}t 150 \\
63.82 \pm 1.7\end{array}$ & & $p$ value \\
\hline E1.5 & $94.36 \pm 2.56$ & 0.016 & $\mathrm{t} 150$ & $63.82 \pm 1.7$ & $<0.001$ & $t 200$ & $47.07 \pm 1.91$ & $<0.001$ \\
\hline E2.0 & $81.99 \pm 2.07$ & $<0.001$ & E1.5 & $94.36 \pm 2.56$ & $<0.001$ & E1.5 & $94.36 \pm 2.56$ & $<0.001$ \\
\hline E2.5 & $73.25 \pm 1.81$ & $<0.001$ & E2.0 & $81.99 \pm 2.07$ & $<0.001$ & E2.0 & $81.99 \pm 2.07$ & $<0.001$ \\
\hline $\mathrm{t} 100$ & $72.86 \pm 2.10$ & $<0.001$ & E2.5 & $73.25 \pm 1.81$ & 0.856 & E2.5 & $73.25 \pm 1.81$ & $<0.001$ \\
\hline $\mathrm{t} 150$ & $63.82 \pm 1.7$ & $<0.001$ & $\mathrm{t} 100+\mathrm{E} 1.5$ & $85.38 \pm 7.43$ & $<0.001$ & $\mathrm{t} 150+\mathrm{E} 1.5$ & $78.94 \pm 1.98$ & $<0.001$ \\
\hline t200 & $47.07 \pm 1.91$ & $<0.001$ & $\mathrm{t} 100+\mathrm{E} 2.0$ & $76.81 \pm 1.83$ & 0.084 & $\mathrm{t} 150+\mathrm{E} 2.0$ & $68.79 \pm 1.46$ & 0.032 \\
\hline $\mathrm{t} 100+\mathrm{E} 1.5$ & $85.38 \pm 7.43$ & $<0.001$ & $\mathrm{t} 100+\mathrm{E} 2.5$ & $65.49 \pm 2.62$ & 0.002 & $\mathrm{t} 150+\mathrm{E} 2.5$ & $60.01 \pm 2.58$ & 0.096 \\
\hline $\begin{array}{l}\text { E1.5 } \\
94.36 \pm 2.56\end{array}$ & & $p$ value & $\begin{array}{l}E 2.0 \\
81.99 \pm 2.07\end{array}$ & & p value & $\begin{array}{l}\text { E2.5 } \\
73.25 \pm 1.81\end{array}$ & & p value \\
\hline E2.0 & $81.99 \pm 2.07$ & $<0.001$ & E2.5 & $73.25 \pm 1.81$ & $<0.001$ & $\mathrm{t} 100$ & $72.86 \pm 2.10$ & 0.856 \\
\hline E2.5 & $73.25 \pm 1.81$ & $<0.001$ & $\mathrm{t} 100+\mathrm{E} 2.0$ & $76.81 \pm 1.83$ & 0.026 & $\mathrm{t} 100+\mathrm{E} 2.5$ & $65.49 \pm 2.62$ & 0.001 \\
\hline $\mathrm{t} 100+\mathrm{E} 1.5$ & $85.38 \pm 7.43$ & $<0.001$ & $\mathrm{t} 150+\mathrm{E} 2.0$ & $68.79 \pm 1.46$ & $<0.001$ & $\mathrm{t} 150+\mathrm{E} 2.5$ & $60.01 \pm 2.58$ & $<0.001$ \\
\hline $\mathrm{t} 150+\mathrm{E} 1.5$ & $78.94 \pm 1.98$ & $<0.001$ & t200+ E2.0 & $51.94 \pm 2.72$ & $<0.001$ & t200+E2.5 & $43.48 \pm 3.20$ & $<0.001$ \\
\hline t200+E1.5 & $72.52 \pm 1.10$ & $<0.001$ & E1.5 & $94.36 \pm 2.56$ & $<0.001$ & $\mathrm{t} 200+\mathrm{E} 2.0$ & $51.94 \pm 2.72$ & $<0.001$ \\
\hline
\end{tabular}

The experiment was repeated five times and the average is reported with standard error for each group. Statistical analysis was performed using one-way analysis of variance (ANOVA) with subsequent post hoc comparisons by POST HOC (LSD) TEST (SPSS 21.0). (unit of measurement = percentage)

t: tert-Butyl hydroperoxide (t-BHP) E: Pyrus biossieriana Buhse leaves extract

t 100 (t-BHP, concentration: $100 \mu \mathrm{M})$, t 150 (t-BHP, concentration: $150 \mu \mathrm{M})$, t 200 (t-BHP, concentration: $200 \mu \mathrm{M}$ ) 
Table 2 The effect of pyrus biossieriana buhse leaf extract and t-BHP treatment on nitrite production in HepG2 cell line

\begin{tabular}{|c|c|c|c|c|c|c|c|c|}
\hline $\begin{array}{l}\text { Control } \\
28.20 \pm 1.15\end{array}$ & & p value & $\begin{array}{l}\mathrm{t} 100 \\
55 \pm 0.97\end{array}$ & & $p$ value & $\begin{array}{l}\mathrm{t} 150 \\
56 \pm 1.16\end{array}$ & & $p$ value \\
\hline E1.5 & $31 \pm 3.33$ & 0.090 & t150 & $56 \pm 1.16$ & 0.573 & t200 & $70 \pm 5.40$ & $<0.001$ \\
\hline E2.0 & $31.80 \pm 1.1$ & 0.020 & E1.5 & $31 \pm 3.33$ & $<0.001$ & E1.5 & $31 \pm 3.33$ & $<0.001$ \\
\hline E2.5 & $48.30 \pm 1.90$ & $<0.001$ & E2.0 & $31.80 \pm 1.1$ & $<0.001$ & E2.0 & $31.80 \pm 1.1$ & $<0.001$ \\
\hline $\mathrm{t} 100$ & $55 \pm 0.97$ & $<0.001$ & E2.5 & $48.30 \pm 1.90$ & $<0.001$ & E2.5 & $48.30 \pm 1.90$ & $<0.001$ \\
\hline t150 & $56 \pm 1.16$ & $<0.001$ & $\mathrm{t} 100+\mathrm{E} 1.5$ & $40 \pm 2.63$ & $<0.001$ & $\mathrm{t} 150+\mathrm{E} 1.5$ & $41 \pm 0.80$ & $<0.001$ \\
\hline t200 & $70 \pm 5.40$ & $<0.001$ & $\mathrm{t} 100+\mathrm{E} 2.0$ & $43.7 \pm 2.80$ & $<0.001$ & $\mathrm{t} 150+\mathrm{E} 2.0$ & $47.40 \pm 30$ & $<0.001$ \\
\hline $\mathrm{t} 100+\mathrm{E} 1.5$ & $40 \pm 2.63$ & $<0.001$ & $\mathrm{t} 100+\mathrm{E} 2.5$ & $59 \pm 0.70$ & $<0.001$ & $\mathrm{t} 150+\mathrm{E} 2.5$ & $60 \pm 0.60$ & $<0.001$ \\
\hline $\begin{array}{l}\text { E1.5 } \\
31 \pm 3.33\end{array}$ & & p value & $\begin{array}{l}\text { E2.0 } \\
31.80 \pm 1.1\end{array}$ & & $p$ value & $\begin{array}{l}\text { E } 2.5 \\
48.30 \pm 1.90\end{array}$ & & $p$ value \\
\hline E2.0 & 31.801 .1 & 0.507 & E2.5 & $48.30 \pm 1.90$ & $<0.001$ & $\mathrm{t} 100$ & $55 \pm 0.97$ & $<0.001$ \\
\hline E2.5 & $48.30 \pm 1.90$ & $<0.001$ & $\mathrm{t} 100+\mathrm{E} 2.0$ & $43.7 \pm 2.80$ & $<0.001$ & $\mathrm{t} 100+\mathrm{E} 2.5$ & $59 \pm 0.70$ & $<0.001$ \\
\hline $\mathrm{t} 100+\mathrm{E} 1.5$ & $40 \pm 2.63$ & $<0.001$ & $\mathrm{t} 150+\mathrm{E} 2.0$ & $47.40 \pm 30$ & $<0.001$ & $\mathrm{t} 150+\mathrm{E} 2.5$ & $60 \pm 0.60$ & $<0.001$ \\
\hline $\mathrm{t} 150+\mathrm{E} 1.5$ & $41 \pm 0.80$ & $<0.001$ & $\mathrm{t} 200+\mathrm{E} 2.0$ & $50.20 \pm 0.60$ & $<0.001$ & $\mathrm{t} 200+\mathrm{E} 2.5$ & $65.6 \pm 0.60$ & $<0.001$ \\
\hline $\mathrm{t} 200+\mathrm{E} 1.5$ & $42.5 \pm 1.94$ & $<0.001$ & E1.5 & $31 \pm 3.33$ & $<0.001$ & $\mathrm{t} 200+\mathrm{E} 2.0$ & $50.20 \pm 0.60$ & 0.190 \\
\hline
\end{tabular}

The experiment was repeated five times and the average is reported with standard error for each group. Statistical analysis was performed using one-way analysis of variance (ANOVA) with subsequent post hoc comparisons by POST HOC (LSD) TEST (SPSS 21.0). (unit of measurement $=\mu M$ )

$\mathrm{t}$ : tert-Butyl hydroperoxide (t-BHP) E: Pyrus biossieriana Buhse leaves extract

t 100 (t-BHP, concentration: $100 \mu \mathrm{M}), \mathrm{t} 150$ (t-BHP, concentration: $150 \mu \mathrm{M}), \mathrm{t} 200$ (t-BHP, concentration: $200 \mu \mathrm{M})$

nitrite results in toxicity, which induces the production of reactive ROS and causes oxidative stress [22]. Pretreatment of cells with the extract only, slightly increased the nitrite production $[31 \pm 3.33 \mu \mathrm{M}$ in the group treated with $1.5 \mathrm{mg} / \mathrm{mL}$ concentration of extract $(\mathrm{p}=0.09)$ and $31.8 \pm 1.1 \mu \mathrm{M}$ in the group treated with $2.0 \mathrm{mg} / \mathrm{mL}$ concentration of the extract when compared to the control group $(p=0.02)]$. Exposure of the cells pretreated with $1.5 \mathrm{mg} / \mathrm{mL}$ of extract to different $\mathrm{t}-\mathrm{BHP}$ doses $(100 \mu \mathrm{M}, 150 \mu \mathrm{M}, 200 \mu \mathrm{M})$ increased the nitrite production to $40 \pm 2.63,41 \pm 0.8$, and $42.5 \pm 1.94 \mu \mathrm{M}$ respectively $(\mathrm{p}<0.001)$. The results showed a decrease in nitrite production in $\mathrm{t} 100 / \mathrm{E} 1.5$ treated group $(40 \pm 2.63 \mu \mathrm{M})$ and $\mathrm{t} 100 / \mathrm{E} 2.0 \mathrm{mg} / \mathrm{mL}$ treated group $(43.7 \pm 2.80 \mu \mathrm{M})(\mathrm{p}<0.001)$ (Table 2). Treatment of the cells with different concentrations of extract revealed that the extract increases the antioxidant capacity in a dose-dependent manner in which treatment of the cells with $1.5,2.0$, and $2.5 \mathrm{mg} / \mathrm{mL}$ concentrations of extract increased this parameter to $1814 \pm 64.85,2498 \pm 37.83$, and $3952 \pm 37.83 \mu \mathrm{M}$ (p values $<0.001$ ). Exposure of $\mathrm{t}$-BHP alone in different doses $(100 \mu \mathrm{M}, 150 \mu \mathrm{M}$, and $200 \mu \mathrm{M})$ reduced the antioxidant capacity in a dosedependent manner to $140 \pm 12.69(\mathrm{p}=0.078), 96 \pm 9.76$ $(\mathrm{p}=0.008)$, and $80 \pm 8.8 \mu \mathrm{M}(\mathrm{p}=0.001)$ respectively when compared to control group. Exposure of the cells treated with $2.0 \mathrm{mg} / \mathrm{mL}$ concentration of the extract to t-BHP concentrations (100 $\mu \mathrm{M}, 150 \mu \mathrm{M}, 200 \mu \mathrm{M})$, showed a slightly decreasing trend in the antioxidant capacity (t100/E2.0, $2438 \pm 32.23, \mathrm{p}=0.03, \mathrm{t} 150 / \mathrm{E} 2.0$, $2294 \pm 30.81, \mathrm{p}<0.001$, and t200/E2.0, $2234 \pm 12.14$, $\mathrm{p}<0.001)$. A similar trend was shown when cells treated with $2.5 \mathrm{mg} / \mathrm{mL}$ concentration of the extract were exposed to $100 \mu \mathrm{M}, 150 \mu \mathrm{M}$, and $200 \mu \mathrm{M}$ concentrations of t-BHP in which the parameter dropped to $3832 \pm 34.49,3508 \pm 23.93$, and $3075 \pm 97.91 \mu \mathrm{M}$ respectively $(\mathrm{p}<0.001)$. (Table 3$)$ Lipids are the most susceptible biological molecules to the attack of ROS and RNS. Lipid peroxidation plays a role in the disturbance of fine structures, functional loss, and permeability of biomembranes and results in production of toxic products which are chemically reactive and covalently modify a variety of biomolecules including DNA bases [23]. TBA assay (TBA test) is widely used to assess the products of lipid peroxidation. From a molecular point of view, the mechanism is based on the MDA (an end product of lipid peroxidation) reaction with TBA and production of a red adduct [24]. The results of TBA test showed that $\mathrm{t}$-BHP alone increased the parameter dose-dependently in which 100,150 , and $200 \mu \mathrm{M}$ concentrations could increase TBA results to $3.17 \pm 0.58$, $3.86 \pm 0.06$, and $5.91 \pm 0.18 \mu \mathrm{M}(\mathrm{p}<0.001)$. Interestingly, all groups pretreated with $1.5,2.0$, and $2.5 \mathrm{mg} /$ $\mathrm{mL}$ concentrations of the extract that were exposed to $200 \mu \mathrm{M}$ concentration of $\mathrm{t}$-BHP, showed the highest rates of lipid peroxidation $[3.76 \pm 0.09,3.96 \pm 0.14$, and $6.23 \pm 1.36 \mu \mathrm{M}$ respectively when they were compared to corresponding groups with the same extract 
Table 3 The effect of pyrus biossieriana buhse leaf extract and t-BHP treatment on antioxidant capacity in HepG2 cell line

\begin{tabular}{|c|c|c|c|c|c|c|c|c|}
\hline \multicolumn{2}{|c|}{$\begin{array}{l}\text { Control } \\
180.10 \pm 14.87\end{array}$} & \multirow{2}{*}{$\begin{array}{l}\text { p value } \\
<0.001\end{array}$} & \multicolumn{2}{|l|}{$\begin{array}{l}t 100 \\
140 \pm 12.69\end{array}$} & \multirow{2}{*}{$\begin{array}{c}\text { p value } \\
0.351\end{array}$} & \multicolumn{2}{|l|}{$\begin{array}{l}\mathrm{t} 150 \\
96 \pm 9.76\end{array}$} & \multirow{2}{*}{$\begin{array}{r}\text { p value } \\
0.486\end{array}$} \\
\hline E1.5 & $1814 \pm 64.85$ & & $\mathrm{t} 150$ & $96 \pm 9.76$ & & t200 & $80 \pm 8.80$ & \\
\hline E2.0 & $2498 \pm 37.83$ & $<0.001$ & E1.5 & $1814 \pm 64.85$ & $<0.001$ & E1.5 & $1814 \pm 64.85$ & $<0.001$ \\
\hline E2.5 & $3952 \pm 37.83$ & $<0.001$ & E2.0 & $2498 \pm 37.83$ & $<0.001$ & E2.0 & $2498 \pm 37.83$ & $<0.001$ \\
\hline t100 & $140 \pm 12.69$ & 0.078 & E2.5 & $3952 \pm 37.83$ & $<0.001$ & E2.5 & $3952 \pm 37.83$ & $<0.001$ \\
\hline t150 & $96 \pm 9.76$ & 0.008 & $\mathrm{t} 100+\mathrm{E} 1.5$ & $1381 \pm 57.96$ & $<0.001$ & $\mathrm{t} 150+\mathrm{E} 1.5$ & $1081 \pm 87.36$ & $<0.001$ \\
\hline t200 & $80 \pm 8.80$ & 0.001 & $\mathrm{t} 100+\mathrm{E} 2.0$ & $2438 \pm 32.23$ & $<0.001$ & $\mathrm{t} 150+\mathrm{E} 2.0$ & $2294 \pm 30.81$ & $<0.001$ \\
\hline $\mathrm{t} 100+\mathrm{E} 1.5$ & $1381 \pm 57.96$ & $<0.001$ & $\mathrm{t} 100+\mathrm{E} 2.5$ & $3832 \pm 34.49$ & 0.002 & $\mathrm{t} 150+\mathrm{E} 2.5$ & $3508 \pm 23.93$ & 0.096 \\
\hline $\begin{array}{l}\text { E1.5 } \\
1814 \pm 64.8\end{array}$ & & $p$ value & $\begin{array}{l}\text { E2.0 } \\
2498 \pm 37.8\end{array}$ & & $p$ value & $\begin{array}{l}\text { E2.5 } \\
3952 \pm 37.8\end{array}$ & & p value \\
\hline E2.0 & $2498 \pm 37.83$ & $<0.001$ & E2.5 & $3952 \pm 37.83$ & $<0.001$ & $\mathrm{t} 100$ & $140 \pm 12.69$ & $<0.001$ \\
\hline E2.5 & $3952 \pm 37.83$ & $<0.001$ & $\mathrm{t} 100+\mathrm{E} 2.0$ & $2438 \pm 32.23$ & 0.03 & $\mathrm{t} 100+\mathrm{E} 2.5$ & $3832 \pm 34.49$ & $<0.001$ \\
\hline $\mathrm{t} 100+\mathrm{E} 1.5$ & $1381 \pm 57.96$ & $<0.001$ & $\mathrm{t} 150+\mathrm{E} 2.0$ & $2294 \pm 30.81$ & $<0.001$ & $\mathrm{t} 150+\mathrm{E} 2.5$ & $3508 \pm 23.93$ & $<0.001$ \\
\hline $\mathrm{t} 150+\mathrm{E} 1.5$ & $1081 \pm 87.36$ & $<0.001$ & $\mathrm{t} 200+\mathrm{E} 2.0$ & $2234 \pm 12.14$ & $<0.001$ & $\mathrm{t} 200+\mathrm{E} 2.5$ & $3075 \pm 97.91$ & $<0.001$ \\
\hline $\mathrm{t} 200+\mathrm{E} 1.5$ & $924.9 \pm 33.78$ & $<0.001$ & E1.5 & $1814 \pm 64.85$ & $<0.001$ & $\mathrm{t} 200+\mathrm{E} 2.0$ & $2234 \pm 12.14$ & $<0.001$ \\
\hline
\end{tabular}

The experiment was repeated five times and the average is reported with standard error for each group. Statistical analysis was performed using one-way analysis of variance (ANOVA) with subsequent post hoc comparisons by POST HOC (LSD) TEST (SPSS 21.0). (unit of measurement $=\mu M$ )

$\mathrm{t}$ : tert-Butyl hydroperoxide (t-BHP) E: Pyrus biossieriana Buhse leaves extract

t 100 (t-BHP, concentration: $100 \mu \mathrm{M}), \mathrm{t} 150$ (t-BHP, concentration: $150 \mu \mathrm{M}), \mathrm{t} 200$ (t-BHP, concentration: $200 \mu \mathrm{M})$

Table 4 The effect of pyrus biossieriana buhse leaf extract and t-BHP treatment on TBA equivalent (lipid peroxidation) in HepG2 cell line

\begin{tabular}{|c|c|c|c|c|c|c|c|c|}
\hline $\begin{array}{l}\text { Control } \\
1.30 \pm 0.04\end{array}$ & & $p$ value & $\begin{array}{l}\mathrm{t} 100 \\
3.17 \pm 0.58\end{array}$ & & $p$ value & $\begin{array}{l}\mathrm{t} 150 \\
3.86 \pm 0.06\end{array}$ & & $p$ value \\
\hline E1.5 & $1.28 \pm 0.06$ & 0.008 & $\mathrm{t} 150$ & $3.86 \pm 0.06$ & $<0.001$ & t200 & $5.9 \pm 0.18$ & $<0.001$ \\
\hline E2.0 & $2.44 \pm 0.03$ & $<0.001$ & E1.5 & $1.28 \pm 0.06$ & $<0.001$ & E1.5 & $1.28 \pm 0.06$ & $<0.001$ \\
\hline E2.5 & $3.16 \pm 0.07$ & $<0.001$ & E2.0 & $2.44 \pm 0.03$ & $<0.001$ & E2.0 & $2.44 \pm 0.03$ & $<0.001$ \\
\hline t100 & $3.17 \pm 0.58$ & $<0.001$ & E2.5 & $3.16 \pm 0.07$ & $<0.001$ & E2.5 & $3.16 \pm 0.07$ & $<0.001$ \\
\hline t150 & $3.86 \pm 0.06$ & $<0.001$ & $\mathrm{t} 100+\mathrm{E} 1.5$ & $2.26 \pm 0.03$ & $<0.001$ & $\mathrm{t} 150+\mathrm{E} 1.5$ & $2.72 \pm 0.07$ & $<0.001$ \\
\hline t200 & $5.91 \pm 0.18$ & $<0.001$ & $\mathrm{t} 100+\mathrm{E} 2.0$ & $2.86 \pm 0.03$ & $<0.001$ & $\mathrm{t} 150+\mathrm{E} 2.0$ & $3.01 \pm 0.05$ & $<0.001$ \\
\hline $\mathrm{t} 100+\mathrm{E} 1.5$ & $2.26 \pm 0.03$ & $<0.001$ & $\mathrm{t} 100+\mathrm{E} 2.5$ & $3.91 \pm 0.07$ & $<0.001$ & $\mathrm{t} 150+\mathrm{E} 2.5$ & $5.72 \pm 0.10$ & $<0.001$ \\
\hline $\begin{array}{l}\mathrm{E} 1.5 \\
1.28 \pm 0.06\end{array}$ & & $p$ value & $\begin{array}{l}\text { E2.0 } \\
2.44 \pm 0.03\end{array}$ & & $p$ value & $\begin{array}{l}\text { E2.5 } \\
3.16 \pm 0.07\end{array}$ & & $p$ value \\
\hline E2.0 & $2.44 \pm 0.03$ & $<0.001$ & E2.5 & $3.16 \pm 0.07$ & $<0.001$ & t100 & $3.17 \pm 0.58$ & $<0.001$ \\
\hline E2.5 & $3.16 \pm 0.07$ & $<0.001$ & $\mathrm{t} 100+\mathrm{E} 2.0$ & $2.86 \pm 0.03$ & $<0.001$ & $\mathrm{t} 100+\mathrm{E} 2.5$ & $3.91 \pm 0.07$ & $<0.001$ \\
\hline $\mathrm{t} 100+\mathrm{E} 1.5$ & $2.26 \pm 0.03$ & $<0.001$ & $\mathrm{t} 150+\mathrm{E} 2.0$ & $3.01 \pm 0.05$ & $<0.001$ & $\mathrm{t} 150+\mathrm{E} 2.5$ & $5.72 \pm 0.10$ & $<0.001$ \\
\hline $\mathrm{t} 150+\mathrm{E} 1.5$ & $2.72 \pm 0.07$ & $<0.001$ & $\mathrm{t} 200+\mathrm{E} 2.0$ & $3.96 \pm 0.14$ & $<0.001$ & $\mathrm{t} 200+\mathrm{E} 2.5$ & $6.23 \pm 1.36$ & $<0.001$ \\
\hline $\mathrm{t} 200+\mathrm{E} 1.5$ & $3.76 \pm 0.09$ & $<0.001$ & E1.5 & $1.28 \pm 0.06$ & $<0.001$ & $\mathrm{t} 200+\mathrm{E} 2.0$ & $3.96 \pm 0.14$ & $<0.001$ \\
\hline
\end{tabular}

The experiment was repeated five times and the average is reported with standard error for each group. Statistical analysis was performed using one-way analysis of variance (ANOVA) with subsequent post hoc comparisons by POST HOC (LSD) TEST (SPSS 21.0). (unit of measurement $=\mu M$ )

t: tert-Butyl hydroperoxide (t-BHP) E: Pyrus biossieriana Buhse leaves extract

t 100 (t-BHP, concentration: $100 \mu \mathrm{M}), \mathrm{t} 150$ (t-BHP, concentration: $150 \mu \mathrm{M}), \mathrm{t} 200$ (t-BHP, concentration: $200 \mu \mathrm{M})$

concentrations $(\mathrm{p}<0.001)]$. Our results showed that the extract suppresses the lipid peroxidation more effectively at 1.5 and $2.0 \mathrm{mg} / \mathrm{mL}$ concentrations (Table 4).

\section{Discussion}

In the present study, it was shown that t-BHP induced strong inhibition on cell growth, and pretreatment with P. biossieriana Buhse leaf extract $(1.5 \mathrm{mg} / \mathrm{mL}$ and $2.0 \mathrm{mg} /$ 
$\mathrm{mL}$ ), significantly protected the HepG2 cells against oxidative damage. In the previous studies, the extract showed significant anti-hyperglycemic and anti-hyperlipemic activity [1]. Besides, it attenuates lipid peroxidation and NO production in t-BHP treated cells. Finally, our results showed that the groups treated with extract only but not $\mathrm{t}-\mathrm{BHP}$, had lower cell viability [E $1.5 \mathrm{mg} / \mathrm{mL}$ ( $\mathrm{p}$ value $=0.016$ ), $\mathrm{E} 2.0 \mathrm{mg} / \mathrm{mL}$ ( $\mathrm{p}$ value $\leq 0.001$ ), and $\mathrm{E}$ $2.5 \mathrm{mg} / \mathrm{mL}$ (P value $\leq 0.001$ )] when compared to the control group. We suggest investigating the effects of commercial arbutin, or other antioxidants reported in extract or the separated fractions of extract in further in vitro and in vivo investigations. The present study showed that $P$. biossieriana Buhse leaf extract attenuates t-BHPinduced cytotoxicity in HepG2 cells. Pretreatment with certain concentrations of extract protected HepG2 cells against alterations induced by t-BHP, probably through quenching radical species, reducing the rate of MDA formation, and $\mathrm{NO}$ production.

\section{Limitations}

Application of an herbal extract according to its complicated chemical composition does not provide data on the synergic effect of components. In this regard, there may be some components that interfere with the desired and expected properties in certain concentrations, for instance in this experiment, application of extract in 1.5 and $2.0 \mathrm{mg} / \mathrm{mL}$ concentrations could effectively protect HepG2 cells. However, when extract was applied in a higher $(2.5 \mathrm{mg} / \mathrm{mL})$ concentration, the effect was partially suppressed. Determining the suppressing (and also those having synergistic effects) components may provide a better insight into the involved molecular mechanisms through which extract influences the biologic parameters studied in this and similar studies. According to our previous studies [2], arbutin was the main antioxidant, however, other extract components with suppressing or synergistic properties are yet to be defined. For instance, it was previously reported that benzoquinone is a chemical found in Pyrus family extract [25] and that it effectively induces apoptosis in hepatoma cell lines [26, 27]. We recommend pretreating the cells with optimized concentrations of arbutin with other components of the extract to assess the effects of arbutin on the parameters.

\footnotetext{
Abbreviations

FRAP: Ferric-reducing antioxidant power; HPLC: High-performance liquid chromatography; MDA: Malondialdehyde; RNS: Reactive nitrogen species; ROS: Reactive oxygen species; TAC: Total antioxidant capacity; t-BHP: tert-Butyl hydroperoxide; TBA: Thiobarbituric acid.
}

\section{Acknowledgements}

We would like to thank the cellular and molecular research center and Deputy of Research, Babol University of Medical Sciences for financial support (Fund number: 98113).

\section{Authors' contributions}

The first draft of the manuscript was written by DEAK All authors participated in material preparation, data collection, and analysis. All authors read and approved the final manuscript. HM and DEAK Contributed to all experimental work. HM, MP, and HP were responsible for overall supervision. AAM and NS Contributed to conception and design. ML, Contributed to all experimental work, data and statistical analysis, and interpretation of data. All authors read and approved the final manuscript.

\section{Funding}

This study was supported by cellular and molecular research center and Deputy of Research, Babol University of Medical Sciences for financial support (Fund number: 98113).

\section{Availability of data and materials}

The datasets used and/or analyzed during the current study available from the corresponding author on reasonable request.

\section{Code availability}

Not applicable.

\section{Declarations}

\section{Ethics approval and consent to participate}

This study was approved by the ethic committee of Babol medical university (EC98113). No human sample was used in this study.

\section{Consent for publication}

Not applicable.

\section{Competing interests}

The authors have no relevant financial or non-financial interests to disclose.

\section{Author details}

${ }^{1}$ Department of Nutrition, School of Allied Medical Sciences, Ahvaz Jundishapur University of Medical Sciences, Ahvaz, Iran. ${ }^{2}$ Department of Biochemistry, School of Medicine, Jahrom University of Medical Sciences, Jahrom, Iran. ${ }^{3}$ Cellular and Molecular Research Center, Cellular and Molecular Medicine Institute, Urmia University of Medical Sciences, Urmia, Iran. ${ }^{4}$ Department of Clinical Biochemistry, Faculty of Medicine, Babol University of Medical Sciences, Babol, Iran. ${ }^{5}$ Cellular and Molecular Biology Research Center, Health Research Institute, Babol University of Medical Sciences, Babol, Iran. ${ }^{6}$ Department of Pharmacology \& Toxicology, School of Medicine, Babol University of Medical Sciences, Babol, Iran. ${ }^{7}$ Neuroscience Research Center, Tabriz University of Medical Sciences, Tabriz, Iran.

Received: 17 March 2021 Accepted: 26 July 2021

Published online: 03 August 2021

\section{References}

1. Shahaboddin ME, Pouramir M, Moghadamnia AA, Parsian H, Lakzaei M, Mir H. Pyrus biossieriana Buhse leaf extract: an antioxidant, antihyperglycaemic and antihyperlipidemic agent. Food Chem. 2011;126(4):1730-3.

2. Seyfizadeh N, Mahjoub PDS, Zabihi E, Moghadamnia A, Pouramir M, Mir $\mathrm{H}$, Khosravi Farsani M, Farideh E. Cytoprotective effects of arbutin against tert-butyl hydroperoxid induced toxicity in Hep-G2 cell line. World Appl Sci J. 2012;19:163-7.

3. Tabar F, Nazari A, Pouramir M, Ashrafpour M, Pourabdolhossein F. Arbutin Improves functional recovery and attenuates glial activation in lysolecethin-induced demyelination model in rat optic chiasm. Mol Neurobiol. 2020;57:3228-42.

4. Dastan Z, Pouramir M, Ghasemi-Kasman M, Ghasemzadeh Z, Dadgar M, Gol M, Ashrafpour M, Pourghasem M, Moghadamnia AA, Khafri S. Arbutin reduces cognitive deficit and oxidative stress in animal model of Alzheimer's disease. Int J Neurosci. 2019;129(11):1145-53. 
5. Tripathi M, Singh BK, Kakkar P. Glycyrrhizic acid modulates t-BHP induced apoptosis in primary rat hepatocytes. Food Chem Toxicol. 2009;47(2):339-47.

6. Feng RB, Wang Y, He C, Yang Y, Wan JB. Gallic acid, a natural polyphenol, protects against tert-butyl hydroperoxide-induced hepatotoxicity by activating ERK-Nrf2-Keap1-mediated antioxidative response. Food Chem Toxicol. 2018;119:479-88.

7. Lee HU, Bae EA, Kim DH. Hepatoprotective effects of irisolidone on tertbutyl hyperoxide-induced liver injury. Biol Pharm Bull. 2005:28(3):531-3.

8. Li Z, Jiang T, Lu Q, Xu K, He J, Xie S, Chen Z, Zheng Z, Ye L, Xu K, et al. Berberine attenuated the cytotoxicity induced by t-BHP via inhibiting oxidative stress and mitochondria dysfunction in PC-12 cells. Cell Mol Neurobiol. 2020;40:1-16

9. Liang F, Fang Y, Cao W, Zhang Z, Pan S, Xu X. Attenuation of tert-butyl hydroperoxide (t-BHP)-induced oxidative damage in hepg 2 cells by tangeretin: relevance of the Nrf2-ARE and MAPK signaling pathways. J Agric Food Chem. 2018;66(25):6317-25.

10. Rosa RM, Moura DJ, Melecchi MI, dos Santos RS, Richter MF, Camarao EB, Henriques JA, de Paula Ramos AL, Saffi J. Protective effects of Hibiscus tiliaceus L. methanolic extract to V79 cells against cytotoxicity and genotoxicity induced by hydrogen peroxide and tert-butyl-hydroperoxide. Toxicol In Vitro. 2007;21(8):1442-52.

11. Donato MT, Tolosa L, Gomez-Lechon MJ. Culture and functional characterization of human hepatoma HepG2 cells. Methods Mol Biol (Clifton, NJ). 2015;1250:77-93.

12. Azadbakht M, Marston A, Hostettmann K, Ramezani M. Biological activity of leaf extract and phenol glycoside arbutin of Pyrus boissieriana. J Med Plants. 2004;3:9-14.

13. Ayumi N, Sahudin S, Hussain Z, Hussain M, Abu Samah NH. Polymeric nanoparticles for topical delivery of alpha and beta arbutin: preparation and characterization. Drug Deliv Transl Res. 2018:9:482-96.

14. Singleton V, Rossi J. Colorimetry of total phenolics with phosphomolybdic-phosphotungstic acid reagents. Am J Enol Viticult. 1964;16:144-58.

15. Siddiqui N, Latif A, Mahmood Z. Spectrophotometric determination of the total phenolic content and spectral fluorescence of the herbal Unani drug Gul-e-Zoofa (Nepeta bracteata Benth). J Taibah Univ Med Sci. 2017;12:360-3.

16. Khodaie L, Bamdad S, Delazar A, Nazemiyeh H. Antioxidant, total phenol and flavonoid contents of two Pedicularis L. species from Eastern Azerbaijan, Iran. Biolmpacts. 2012:2:47.
17. Mosmann T. Rapid colorimetric assay for cellular growth and survival: application to proliferation and cytotoxicity assays. J Oflmmunol Methods. 1983;65:55-63.

18. Lima C, Fernandes-Ferreira M, Pereira-Wilson C. Phenolic compounds protect HepG2 cells from oxidative damage: relevance of glutathione levels. Life Sci. 2006;79:2056-68.

19. Thaipong K, Boonprakob U, Crosby K, Cisneros-Zevallos L, Byrne D. Comparision of ABTS, DPPH, FRAP, and ORAC assays for estimating antioxidant activity from guava fruit extracts. J Food Compos Anal. 2006;19:669-75.

20. Jie S, Zhang X, Mark B, Harry F. Measurement of nitric oxide production in biological systems by using griess reaction assay. Sensors. 2003;3:276-84.

21. Fraga CG, Leibovitz BE, Tappel AL. Lipid peroxidation measured as thiobarbituric acid-reactive substances in tissue slices: characterization and comparison with homogenates and microsomes. Free Radical Biol Med. 1988;4(3):155-61.

22. Cheng $\mathrm{CH}$, Su YL, Ma HL, Deng YQ, Feng J, Chen XL, Jie YK, Guo ZX. Effect of nitrite exposure on oxidative stress, DNA damage and apoptosis in mud crab (Scylla paramamosain). Chemosphere. 2020;239:124668.

23. Niki E. Lipid peroxidation products as oxidative stress biomarkers. BioFactors (Oxford, England). 2008:34(2):171-80.

24. Garcia YJ, Rodríguez-Malaver AJ, Peñaloza N. Lipid peroxidation measurement by thiobarbituric acid assay in rat cerebellar slices. J Neurosci Methods. 2005;144(1):127-35.

25. Jin S, Sato N. Benzoquinone, the substance essential for antibacterial activity in aqueous extracts from succulent young shoots of the pear Pyrus spp. Phytochemistry. 2003;62:101-7.

26. Baigi M, Brault L, Néguesque A, Beley M, Hilali R, Gaüzère F, Bagrel D. Apoptosis/necrosis switch in two different cancer cell lines: Influence of benzoquinone- and hydrogen peroxide-induced oxidative stress intensity, and glutathione. Toxicol In Vitro. 2008;22:1547-54.

27. Pardo-Andreu G, Reis F, González Durruthy M, Delgado Hernandez R, D’Vries R, Berghe W, Alberici L. Rapanone, a naturally occurring benzoquinone, inhibits mitochondrial respiration and induces HepG2 cell death. Toxicol In Vitro. 2019;63:104737.

\section{Publisher's Note}

Springer Nature remains neutral with regard to jurisdictional claims in published maps and institutional affiliations.
Ready to submit your research? Choose BMC and benefit from:

- fast, convenient online submission

- thorough peer review by experienced researchers in your field

- rapid publication on acceptance

- support for research data, including large and complex data types

- gold Open Access which fosters wider collaboration and increased citations

- maximum visibility for your research: over 100M website views per year

At BMC, research is always in progress.

Learn more biomedcentral.com/submissions 